\title{
Punctuation Relevance in Subtitle: The Foreign Audience Example
}

\author{
Christopher Chinedu Nwike \\ Department of Linguistics, Igbo and Other Nigerian Languages, University of Nigeria, Nsukka, Nigeria
}

\begin{abstract}
This study looked at punctuation mark and their relevance in written information although; the objective of the study is to discover the relevance of punctuation mark in subtitle: The Foreign audience example and to re-echo the need to have a well punctuated write-up in literary genres. The study sees language as a system of human communication. The problem of the study sets in from lots of poor and wrongly applied punctuations, as various forms of signs are seen to be used in some of the movies of the entertainment industry - Nollywood, which in turn, gives rise to wrong interpretation to the foreign audience of that language, and as such, the foreign learner of a particular language, the Igbo example will not enjoy the supposed information. The study adopted the framework of Vinay and Darbelnet principles and strategies as a guide to solving the problem as one of its principles - equivalence was used to relate the movie wrong punctuated subtitles to their supposed target language. The methodology of explication is equally adopted while the study concludes that punctuation errors are involved with wrong application of punctuation mark to written discourses on where it is not supposed to be since punctuation occurs only in written discourses and not spoken.
\end{abstract}

Index Terms - language, punctuation, subtitle

\section{INTRODUCTION}

Language as a means of human communication is an act which can be done either by spoken or written, while consisting of the use of words in a structured and conventional way. According to Julie and Deborah (2010), it can as well be any method of expression or communication which can be called a body language. Due to its divers use, it can be the system of communication used by a particular community or country as well as the phraseology and vocabulary of a particular group. In other words, it can be the manner or style of a piece of writing or speech which can be crude, bad or offensive language as well as foul or a strong language. For Julie and Deborah (2010), language is a form of interaction that exists in the human environment, and this is why people who go into active communication understand the language use of a particular society.

Languages play an important role in the human environment. However, before communication is properly used, correct language use must have been taken place especially in the areas of spoken or written languages. Based on this study, focus is not on the spoken language but written language of the movie that is used for this study titled Onye Bu Nna M. The study is set to look at the re-expression of the spoken utterances of the source information in the written form and re-echoing the need to have a well punctuated write-ups in literary genres of this kind in order to arouse the interest of the foreign audience who may be a foreign language learner of a particular language, or hard of hearing patients or people who their hearing faculty is impaired to properly understand the message of the source movie. In line with this, it can be announced that punctuation plays a vital role in any written language as it guides the reader on how to go about reading the subtitled information on the screen. However, punctuation can be defined as the signs and symbols that are used to give more meaning to written information. It can said to be used in writing in order to separate sentences and their elements as well as to clarify meanings. Punctuation mark is made up of different signs and symbols for writing. Categorically, punctuation is involved with imputing the supposed signs and symbols used in writing things in order to put a clear distinction between different meanings in a sentence(s) (Challay and Jones, 2019). Punctuation helps to bring the meaning of a particular message down to the target audience because, each sign or symbol has what it represents. Punctuation errors are involved with wrong application of punctuation marks to written discourses. However, punctuation occurs only in written discourses and not spoken. So, in this study, there is need to point out the few possible wrong applications as it goes against the rules of the use of punctuation mark. Based on this, there are some common mistakes in the use of punctuation. For instance, avoid using exclamation marks (!) in academic writing as well as never to combine a question mark and an exclamation mark (?!) or use multiple signs (!!!/ ???). Again, avoid using ellipses (...) at the end of your sentences but only use it to indicate omission in quoting. More so, don't use apostrophes to make plurals, for instance, the 1990's. Watch out for misplaced commas and then, if you are uncertain, read your sentence loud and see if there is a natural pause. In line with the following, it can be seen that the previous assertions are the common errors in punctuation that leads to wrong use of punctuation in a written statements. The symbols or signs can be full stop, comma, brackets, colon, apostrophe etc. On the other hand, according to Raimes and Ann (2004), they believed that comma's can be used before a conjunction such as and, but, or, nor, so, far, yet in order to connect independent clauses. For instance Emeka was upset, but Onyinye did not understand why he was worried. 
Commas indicate a separation of ideas or elements within the structure of a sentence. Also, a comma is used to separate three or more words, phrases, or clauses (sentence parts) in a series. Again, a comma indicates the beginning of a phrase or word which moved from the end of the sentence and also, it is used between independent clauses by a coordinating conjunction of the English language. For example, for, and, nor, but, or, yet, so. Again, it can be applied before and after extra thus, nonrestrictive information included in a sentence like extra commas for extra information. For instance, after the quarrels, the neighbours complained. Furthermore, comma's can be applied in different contexts and due to the vast nature of its function; it can be used around transitional expressions. For instance, my mother, a groundnut seller, works late at night. Again, it separates three or more items in a sentence and this can be exemplified thus, the beginning, however, is discouraging. In the sentence of the English language according to Raimes and Ann (2004), punctuation occurs between coordinate evaluative adjectives. For instance, they ordered red oil, potatoes and yam. Then, it is also used after a verb that introduces a quotation. For instance, she ate a less expensive, delicious and well prepared meal at Ikenga hotel, Nsukka.

In line with the above, information, Challay and Jones (2019) state that there are functions of the other different punctuation mark in a language, and one of them is quotation mark. It shows title of a short work as well as the end and beginning of a quotation. Quotation marks " " enclose the exact words of a person. More so, on the part of parentheses for instance, it tries to let go of the units within a sentence that are related to the sentence with no meaning which in other words, it can be said that it removes unnecessary words from a sentence. So, when parentheses are used to enclose an independent sentence, the end punctuation belongs to inside the parentheses.

Additionally, Challay and Jones (2019) said that apostrophe is one of the punctuation that exists. Apostrophes show possession and also indicate where a letter has been omitted to form a contraction. However, an apostrophe is only added for plural possessive nouns ending in s. Also, an apostrophe can come into a word or phrase when noun is more than one, for instance, - student's bag (a student), students' books (more than a student). In the English language, hyphen is used when a compound word is formed or when one wants to join word elements or units as well as letters to words, prefixes and suffixes. In a sentence, colons mostly follow an independent clause as it draws it raises concern to the data or information that comes follows after it. So, it can be said that one can see a colon after the independent clause or complete sentence. More so, dashes try to link group of words to other groups in order to make emphasis. Again, semicolon is one of the punctuation ';'. However, semicolons separate clauses or phrases that are related, and that receive equal emphasis.

In connection with the above, irrespective of the different applications of punctuation in a sentence of a particular language, the English example, there are still rules that govern where and where not punctuation can be applied. For instance, as punctuation tries to give clarity or sense to what that is written in particular language, an example of comma is not used to separate a verb from its subject. For instance, she gasped, "We haven't a moment to lose!" Again, the non application of comma extends within a compound structure when the second part of the compound is not an independent clause. For instance, interviewing so many students in Linguistics department, University of Nigeria, Nsukka, helped the researcher understand the "student's dream" More so, after a coordinating conjunction that connects two sentences, comma goes only before conjunction and this can be exemplified thus, Oluwanedu has written novels, and adapted them for the screen play. Additionally, in order to connect two independent clauses when no coordinating conjunction is present, comma is used. For instance, Unigwe Chidalu's show is supposed to be good, but, I missed it when it came to my local theater. However, this example can be related to the other forms of punctuations as it will help writers or people who subtitle to give clarity to their messages towards their target audience, especially in the areas of translation where the translator who adopts a dynamic equivalence decides most of the things for the target audience while not following the conformities of the literal translation. For Nida (1964), a free or dynamic equivalence suggests that such translations enable people to better understand the original text, therefore, it is better. Gentzler (1993) added that Nida's dynamic equivalence carries the target audience along not minding the culture of the source text and ideas of discourse.

Due to the need and the essence of punctuation in a written information which on the other hand touches the areas of media translation or audiovisual translation, there is need to bring their relevance to limelight as poor punctuated information in subtitles misleads or throws the target audience who may not actually understand the source language off balance. However, subtitle exercise did not just emerge rather; it came into use in order to solve problems. The problem touches the reasons why subtitles are done which in other words; one can say that it helps a foreign language learner of a particular language to study a particular language. It equally helps people who have hearing impairment to read up the information on the screen and still appreciate the information like every other person, and also for the people who suffer hard of hearing. However, one may actually subtitle for fun as to make the same information available to a particular community whose language falls among the minority languages for documentation sake. Looking at these motives, it is discovered that the subtitles of the translation house of the entertainment industry in Nigeria, there are lots of poor and wrongly applied punctuation and as such, gives wrong interpretation to the foreign audience of that language. Various forms of signs are seen to be used in some of the movies of the entertainment industry - Nollywood and as such, the foreign learner of a particular language, the Igbo example will not enjoy the supposed information, and this is a problem. Due to this, the study sets to work on punctuation and its relevance in subtitles: The Foreign audience example as its signification will enlighten people who do subtitles to focus more on the proper use of subtitles. Also, on the part of the 
people who do publications or translations, it will concientise them on its relevance, reminding them of the negative effect that possible poor punctuation may cause their patronage and also the target audience. Categorically, all the ills pointed out in this study comes together to form the problems of the study.

\section{THEORETICAL STUDIES}

Translation is involved with information exchange from one language to the other where the information that owns the original message is referred as the source language and the target language for the language that is used to accept the information. For Lecercle (2019), translation involves a transfer of meaning from the source to the target language, thus translating only what makes sense - etymological translation. The work of Nwike (2019) sees translation as one that involves dissemination of information from one language to another which brings about the cross fertilization of culture amongst people.

In trying to reveal what a translation is; Battistón (2019) came up with what he called a standard translation where it is seen from the part of the unidirectional and bipartite hence, from a single ST in one language. According to Battistón (2019), it is a single target text that is produced in another language. Battistón equally introduces what multitarget translations are. However, it involves the translations which produce multiple target texts from a single source text. For instance, a work titled a tour de force is what Nicholas Moore renders as Baudelaire's single poem "Spleen" into more than thirty different poems in English. On the other hand, Battistón (2019) introduces multisource translations. On this, it can be called a translation that produces a single target text from more than one source text although, there are methods or strategies translators or the people who subtitle movies adopt in transferring a particular information, either on textual basis or paratextual grounds. Herein, textual translation involves book translation while paratextual is a non book transfer such as media or audio visual translation. This audiovisual translation touches the areas of dubbing and subtitles. However, the punctuation this study will look at will be based on the ones made in a movie titled Onye bu Nna $m$. In order to see exactness in the translated information on the screen or text, Vinay and Darbelnet (1995) came up with translation principles and strategies one can use during the transfer. The principles are as follows,

\section{A. Adaptation}

This can be called a method devised by the translator to represent the information of the source text that has no equivalence in the target text. However, the basic goal of the translator in this type of principle is to have a similar effect on the TL readers, by domesticating it with the cultural terms. For instance, in the Igbo example,

1a. When he came back, he kissed the wife

b. Mgbe ọ lọtara, o biri nwunye ya ọma/ Mgbe ọ lọtara ọ makụrụ nwunye ya.

In (1a) the Europeans kiss as a sign of welcome but in the Igbo culture as in (1b) hug and embrace are used to welcome one.

\section{B. Borrowing}

This is involved with the situation where encountered information of the source text has no form of equivalence or resemblance in the target language and the translator picked directly a word of the source language and document it in the target (Nwike, 2019). The procedure is normally used when a term does not exist in the TC, or when the translator tries to get some stylistic effects. It can be pure, if there is no change of any kind in the foreign term. Again, if the word has some changes in the spelling, and perhaps some morphological or phonetic adaptation, the pronunciation pattern of the words could be formed in domesticating the word.
English
a. Diskette
German
b. Format
Disquete
Formatear

\section{Calque}

Calque is a form of literal translation which can occur either as lexical or structural of a foreign word or phrase imitates the morphological structure of the source word, but not its pronunciation. For instance,
English
a. Bread
Igbo
b. Phonology
Bùréèdì
c. Football
Fònólójì
fùtùbóòlù

In the case of football, using the same term in Spanish would be a pure borrowing; the word fútbol would be a naturalised borrowing, and balompié a calque.

\section{Equivalence}

Equivalence is a method that is used by the translators to represent same information of the source text in the target. (Vinay and Darbelnet 1995). For instance,

\section{English}

a. He is cunning as a fox

b. A stitch in time saves nine
Igbo

Ọ na-aghọ aghụghọ dịka mbe

E mee ngwa, e meghara ọdachi 


\section{E. Literal translation}

This is a type of translation that is done in order to win the syntactic effect of the original text without first considering the meaning. For instance,

\section{English French Igbo}

John loves Mary Juan ama a María John hụrụ Mary n'anya

From the forgoing, the preposition ' $a$ ' in French is used because; it is a requirement for direct objects denoting a person in French language

\section{F. Modulation}

For Vinay and Darbelnet (1995), modulation involves the use of different terms and phrases of the target language to represent the message of the source language while still maintaining the meaning of the original. Example,

\section{English French Igbo}

Neither head nor tail Ni pies ni cabeza Isi ma ọ bụ ọdụ

So, it is similar to transposition and, sometimes, necessary in order to avoid lack of fluency or exoticism in the translation.

\section{G. Transposition}

This principle is involved with a change in the different parts of speech of a sentence during information transfer. However, in this type of translation, the part of the sentence which seems to be a subject in the source language will change to be at the place of the object or the complement of the sentence. Example,

\section{English}

b. I knocked him down Le derribé de un golpe Agbatụrụ m ya n'ala
Aside from the above information, Chesterman (1997) believes that in translation strategies, there is considerable

French terminological confusion in the sense that it involves the following

1. must be goal oriented,

2. involves text manipulation,

3. must be problem centered,

4. must be applied to the process

5. must be applied in a conscious way

6. must be empirical and understandable for the readers not the person who used them.

From the above highlights, Chesterman (1997) means that at first, one who translates shall read and comprehend a text. Second, he shall analyse the differences between the source and the target texts, and one shall decide on the kind of strategies to use. And finally, one shall produce the equivalent text in the target language. Moreover, according to Chesterman (1997), there are local translation strategies and they are categorized into:

1. Semantics,

2. Syntactic, and

3. Pragmatic changes.

So, in translating allusion, Richards (1985:68) states that proper names (PNs) are names of persons, place or thing, which in a literary work, it plays essential role and are spelt with an initial capital letter. However, there are some models for rendering PNs in translations. According to Harvey and Higgins (1989), they are as follows:

1. The name can be taken over, unchanged from the ST to the TT

2. It can be adopted to conform to the phonic/graphic conventions of the TL.

From the above information, Harvey and Higgins (1989) believe that the former is exotics, which is more like a literal translation and involves no cultural transposition and while the later, a transliteration.

\section{METHODOLOGY}

The methodology of explication is adopted since the study is qualitatively based as well as emergent design approach. The yardstick for this adoption of this emergent design approach is because of the nature of the work. However, the emergent design approach adapts to the new ideas that comes up in the course of carrying out a qualitative research especially when focus is on a particular thing as the study focuses on the movie titled Onye Bụ Nna M.

\section{Data PResentation AND ANALYSis}

This part shows the wrong punctuation in the subtitles of the movie entitled Onye Bu Nna M. These errors may be as a result of style or the way the subtitle was made and so, it then pose a challenge in the rendering of the correct subtitles of the Igbo movie used for the study correctly in a way that the foreign audience will understand the intended message of the movie. However, the data analysis of this study is strictly presented and discussed below based on the objectives of the study hence, to discover the relevance of punctuation mark in subtitle: The Foreign audience example and to re- 
echo the need to have a well punctuated write-up in literary genres. However, the punctuation errors are as follows below:

\begin{tabular}{|c|c|c|}
\hline Igbo Language & Movie English Subtitle & Correct punctuations \\
\hline Keduzi nke ije abal[a ? & Why this night journey $\S$ & Why this night journey? \\
\hline Chere, I mean ihe a [ na-akqwa? & Wait do you mean what you're saying $\S$ & Wait, do you mean what you are saying? \\
\hline $\begin{array}{l}\text { Chere Neka, [ d[kwa serious n'ihe a [ na- } \\
\text { ekwu? }\end{array}$ & $\begin{array}{l}\text { Wait Nneka so you're actually serious about } \\
\text { what you're are saying } \S\end{array}$ & $\begin{array}{l}\text { Wait Nneka, so you're actually serious about } \\
\text { what you're are saying? }\end{array}$ \\
\hline Kee $x d[$ ihe bx ihe $a ?$ & What type of thing is this $\S$ & What type of thing is this? \\
\hline Qkwa [ hxrx na obodo any[ a? & You see this very community $\S$ & You see this very community? \\
\hline $\mathrm{D}[\mathrm{ka} \mathrm{g}[\mathrm{n}[?$ & Like what $\S$ & Like what? \\
\hline Kee ihe [ na-akq ihe a? & What are you even saying $\S$ & What are you even saying? \\
\hline \{ na-ege $\mathrm{m} \mathrm{nt}[?$ & Are you listening $\S$ & Are you listening? \\
\hline $\begin{array}{l}\text { Qkwa [ mara nwata nwany[ a d[ qcha na- } \\
\text { aga achqta } \mathrm{m} \text { toro ogologo? }\end{array}$ & $\begin{array}{l}\text { Do you know that very young girl that do } \\
\text { visit me } \S\end{array}$ & Do you know that young girl that visits me? \\
\hline $\begin{array}{l}\text { A na-ekwu ka a na-ekwu, nwata } \\
\text { nwany[ nqrq n'elu bed p[wa phone }\end{array}$ & $\begin{array}{l}\text { Just in same time the girl started browsing } \\
\text { through phine in bed }\end{array}$ & $\begin{array}{l}\text { Just in same time, the girl started browsing } \\
\text { through phone in bed. }\end{array}$ \\
\hline Maka a p[wakwaraa ihe a, uche ha apxq & $\begin{array}{l}\text { Cos once they start that chatting they lose } \\
\text { concentration }\end{array}$ & $\begin{array}{l}\text { because, once they start that chatting they lose } \\
\text { concentration. }\end{array}$ \\
\hline $\mathrm{Q} g[\mathrm{n}[\mathrm{me} ?$ & What happened $\S$ & What happened? \\
\hline Kee etu I mee & How are yiou $\S$ & How are you? \\
\hline Sam, ya oteela I mewere? & Sam its long you've been doing $\S$ & Sam, its long you've been doing? \\
\hline Nwanne g[ nwoke as[rq g[, [ s[ ya & If your does not say to you you'll say to him & $\begin{array}{l}\text { If your brother did not say to you, you will say to } \\
\text { him. }\end{array}$ \\
\hline $\begin{array}{l}\text { Kee ka m ga-esi mara nke m ga-ekwe } \\
\text { k[taa? }\end{array}$ & $\begin{array}{l}\text { How will I know which one to believe right } \\
\text { now } \S\end{array}$ & How will I know which one to believe right now? \\
\hline $\begin{array}{l}\text { Ngwanx biko ka any[ mee sq sq out or ka } \\
\text { any[ mee half, sq sq half }\end{array}$ & $\begin{array}{l}\text { Ok then. Please, just once Or lets do half. } \\
\text { Just half }\end{array}$ & $\begin{array}{l}\text { Ok then. Please, just once Or lets do half, Just } \\
\text { half. }\end{array}$ \\
\hline Kee ihe [ s[r[ na q bx ya na-eme g[? & What did say is wrong with you§ & What did say is wrong with you? \\
\hline $\begin{array}{l}\text { Ihe } m \text { na-akqgheri bx ad[m ime. Q kwa } \\
\text { ihe } m \text { na-agwa g[ na } m x \text { aahqgh[ ka o } \\
\text { mee }\end{array}$ & $\begin{array}{l}\text { The rubbish am talking is that am pregnant } \\
\text { Same thing I was warning you I wouldn't } \\
\text { like to happen }\end{array}$ & $\begin{array}{l}\text { The rubbish am talking is that am pregnan. Same } \\
\text { thing I was warning you I wouldn't like to } \\
\text { happen. }\end{array}$ \\
\hline Onye? & Who $\S$ & Who? \\
\hline Kedu ka I siri chqta ebe a? & How did you locate this place $\S$ & How did you locate this place? \\
\hline Q bx etu a ka mma? & Is this the best way $\S$ & Is this the best way? \\
\hline $\begin{array}{l}\text { Ihe nke a pxtara bx na } \mathrm{mx} \\
\text { aghqtagh[ agwa } \mathrm{g}[\text { nke ikpe azx a }\end{array}$ & $\begin{array}{l}\text { What this means, is that I don't understand } \\
\text { your behavior this lastly }\end{array}$ & $\begin{array}{l}\text { What this means is that I don't understand your } \\
\text { behavior this lastly. }\end{array}$ \\
\hline Esisielam nri, b[a ka [ b[a rie nri & I'm done cooking. Come have dinner & I'm done cooking. Come have dinner. \\
\hline $\begin{array}{l}\text { Onweghi ihe } \mathrm{m} \text { mere. } \mathrm{O} \text { nweghi ihe } \mathrm{m} \\
\text { mara } \mathrm{m} \text { mee } \mathrm{g}[\end{array}$ & $\begin{array}{l}\text { I don't know what I did. I don't know if I did } \\
\text { anything to you }\end{array}$ & $\begin{array}{l}\text { I don't know what I did. I don't know if I did } \\
\text { anything to you. }\end{array}$ \\
\hline $\begin{array}{l}\text { Ahxkwara m g[ n'anya, q bxgh[ ring ga- } \\
\text { ebutere mx na g[ esemokwu }\end{array}$ & $\begin{array}{l}\text { I love you. its not ring that should bring us } \\
\text { quarrel }\end{array}$ & $\begin{array}{l}\text { I love you, its not ring that should bring us } \\
\text { quarrel. }\end{array}$ \\
\hline $\begin{array}{l}\text { Q bxrxnx ring ka [ chqrq, ring juru n'ie } \\
\text { ah[a, m jee ah[a m kpote ring mkponye } \\
\mathrm{g}[\end{array}$ & $\begin{array}{l}\text { If it is ring you want there are uncountable of } \\
\text { it in the market when go to market I } 11 \text { get } \\
\text { you enough of it }\end{array}$ & $\begin{array}{l}\text { If it is ring you want, there are uncountable of it } \\
\text { in the market. when go to market, I ll get you } \\
\text { enough of it. }\end{array}$ \\
\hline Nnem kee ka q ga-esi d[ mma? & My dear. how will it be well & My dear, how will it be well? \\
\hline $\begin{array}{l}\text { Ajxqla } \mathrm{m} g[\text {, mmadx abxq nwere temper } \\
\text { problem, ha a na-anq n'otu xlq? }\end{array}$ & $\begin{array}{l}\text { Does two people that with temper problem } \\
\text { stay in one house } \S\end{array}$ & $\begin{array}{l}\text { Does two people that with temper problem stay in } \\
\text { one house? }\end{array}$ \\
\hline $\begin{array}{l}\text { Ihe } \mathrm{m} \text { chqrq } \mathrm{k} \text { [taa bx etu } \mathrm{mx} \text { na nwam } \\
\text { nwany[ ga-eji na-ad[ na mma }\end{array}$ & $\begin{array}{l}\text { The only thing I want right now is how be in } \\
\text { good terms with my daughter }\end{array}$ & $\begin{array}{l}\text { The only thing I want right now is how be in } \\
\text { good terms with my daughter. }\end{array}$ \\
\hline $\begin{array}{l}\text { Kee ka [ ga-esiebe isi tiri bata b[a na- } \\
\text { achq onye ga-enye g[ ugwu? }\end{array}$ & $\begin{array}{l}\text { How can you just from wherever barge in } \\
\text { here looking for who will give you respect } \S\end{array}$ & $\begin{array}{l}\text { How can you just from wherever, barge in here, } \\
\text { looking for who will give you respect? }\end{array}$ \\
\hline $\begin{array}{l}\text { Mx na ezinxlq } m \text { na nd[ be any[ na- } \\
\text { ad[ g[ ka nd[ ara }\end{array}$ & $\begin{array}{l}\text { I and my family all seem to you like crazy } \\
\text { ones }\end{array}$ & I and my family all seem to you like crazy ones. \\
\hline Q gagh[ ege g[ nt[ maka na qtaka ahxhx & She wont listen to you. shes suffered a lot & She won't listen to you, she's suffered a lot. \\
\hline Papa biko ewenarx $m$ iwe & Papa please don't be angry with me ok $\S$ & Papa, please don't be angry with me $o k ?$ \\
\hline $\begin{array}{l}\text { M ka ga ab[a hx g[. q kwanx qrx, qrx } \\
\operatorname{kar}[\mathrm{r}[\mathrm{m} \text { ahx, biko ewela iwe }\end{array}$ & $\begin{array}{l}\text { I will still come and see you its just work I } \\
\text { am very much occupied with work please do } \\
\text { not be angry }\end{array}$ & $\begin{array}{l}\text { I will still come and see you, its just work, I am } \\
\text { very much occupied with work, please do not be } \\
\text { angry. }\end{array}$ \\
\hline \multirow[t]{2}{*}{$\begin{array}{l}\text { Etu m si were hx ya bx nwa, o nwekwara } \\
\text { mwute na xd akwa o bere ebe a... }\end{array}$} & $\begin{array}{l}\text { The way am looking at that man he's deeply } \\
\text { pained cos the way he cried here today... }\end{array}$ & $\begin{array}{l}\text { The way am looking at that man, he's deeply } \\
\text { pained cos, the way he cried here today... }\end{array}$ \\
\hline & SEASON TWO & \\
\hline $\begin{array}{l}\text { Qkwanx qtuu afqrq ka m sin a mahadum } \\
\text { pxta }\end{array}$ & $\begin{array}{l}\text { Is it not just one year left and I will graduate } \\
\text { from the university } \S\end{array}$ & $\begin{array}{l}\text { Is it not just one year left and I will graduate from } \\
\text { the university. }\end{array}$ \\
\hline Ọ bụgh[ Nneka? & Is it not Nneka $\S$ & Is it not Nneka? \\
\hline
\end{tabular}


From the above information under the correct punctuation, words that come before any correct punctuation are put in slant. Correct punctuation passes across the right information to the target audience. When the essence of the information is defeated due to wrong punctuation, it then implies that there is information lose. However, the researcher adopted the principle of equivalence in the proposition of Vinay and Darbelnet (1995) that emphasizes on sameness of the information that are of the same source. The relevance of punctuation is very paramount in every written languages especially in screen plays in the sense that it is what that will give guide to the understanding of the written information. When an utterance is verbalized, the tonality of the speaker punctuates every dick and harry of the statement which seem understandable to the listener but when that same information is written down, there is lose of tonality in the real sense. In punctuation, the marks that appear in it are what that are used in different situations and they represent different things and equally serve different functions. Taking an instance from the above information in the table, the utterance says 'O bụgh[ Nneka?' in the movie "Onye bu nna m” Imagine when or where a non speaker of Igbo or a foreigner is watching the movie and gets across the subtitle that lacks the actual punctuation, you will see that the person will see it as plain statement thus, 'Is it not Nneka' which is not actually a statement with question tag, and the supposed message will be lost. In other words, such statements are wrong because, they are not the intended messages. But in a situation where the right punctuation mark are used to pass across the right information, a foreign language learner of Igbo language and a non speaker of Igbo will understand that the actor is asking about Nneka hence, 'Is it not Nneka? So, in order to have the right information to be passed across, the idea of Vinay and Darbelnet (1995) under equivalence was used while the correct punctuation is substituted against the former and additions were made. The sameness came into scene where the intended message in Igbo was rightly rendered into English, still maintain the flavour of the original information thus 'Is it not Nneka§' for 'Is it not Nneka?'

\section{SUMMARY AND CONCLUSION}

In discovering the relevance of punctuation: The Foreign audience example, punctuation helps to bring clarity to any written information. Any information that lacks good punctuation tends to mislead or give false message as well as wrong interpretation to the reader or the target audience. However, this study finds out that punctuated information gives clarity on the follow up of written information. Again, the study finds out that punctuation helps to bring the meaning of a particular message down to the target audience because; each sign or symbol in punctuation has what it represents. On the contrary, it is discovered that punctuation errors are involved with wrong application of punctuation marks to written discourses on where it is not supposed to be since punctuation occurs only in written discourses and not spoken. In other words, the study finds out that punctuation is the practice of imputing the right signs and symbols in written matter in order to make explicit the meaning and separate structural units. On the target audience, the study discovered that there are rules that guide the use of punctuation mark which leads to common mistakes when it is inappropriately used. The study then reveals that exclamation marks (!) are not used in academic writing except in special cases. It equally finds out that question mark and an exclamation mark (?!) are never combined and finally concludes that translation is not just an interlinguistic process of information use or transfer but a more complex exercise which is more than just replacing a source language text with a target language text.

\section{REFERENCES}

[1] Challay, S. \& Jones, H.Y. (2019). A study of the errors in the use of capitalisation among junior secondary school pupils in Bo district. International Journal of Social Sciences and Management. Vol. 6, Issue-4: 90-96. DOI: 10.3126/ijssm.v6i4.26222.

[2] Chesterman, A. (1997). Memes of translation: The spread of ideas in translation theory. Amsterdam: John Benjamins.

[3] Gentzler, E. (1993). Contemporary translation theories. London: Routledge.

[4] Hervey, S. \& Haggins, I. (1992). Thinking translation: A course in translating method, French to English. USA: Routledge

[5] Julie, S. A. \& Deborah, J. V. (2010). American English: History, Structure and Usage. Cambridge: Cambridge University Press. ISBN: 9780521617888.

[6] Lecercle, J. (2019). Modalities of translating nonsense. Translation Studies. Retrieved from https://doi.org/10.1080/14781700.2019.1601129.

[7] Matías B. (2019). How I did not translate Beckett, Translation Studies. Translation Studies. DOI: 10.1080/14781700.2019.1602562. Retrieved from https://doi.org/10.1080/14781700.2019.1602562.

[8] Nida, E. A. (1964). Toward a science of translation. Leiden: Brill.

[9] Nwike, C. C. (2019). Issues and challenges in translating legal text from English to the Igbo language. M. A Dissertation, Department of Linguistics, University of Nigeria, Nsukka.

[10] Raimes and Ann. (2004). Basic rules of punctuation. The speaking, arguing, and writing program. Retrieved on November $2^{\text {nd }}$, 2020 from www.mthoyloke.edu/saw

[11] Richard, A. (1985). Longman dictionary of applied linguistics. Leiden: Brill.

[12] Vinay, J. P. \& Darbelnet, J. (1995). Comparative stylistics of French and English: A methodology for translation. Amsterdam/Philadelphia: John Benjamins. 
Christopher C. Nwike is a native of Onitsha, Onitsha North Local Government Area of Anambra State. He was born in Ogidi, Anambra State on the $3^{\text {rd }}$ of May. Christopher C. Nwike obtained a Bachelor of Arts degree in Linguistics/Igbo in the department of Linguistics, Igbo and Other Nigerian Languages, University of Nigeria, Nsukka Enugu State in 2015. Also, he obtained a Master of Arts degree in Translation and Interpretation in the department of Linguistics, Igbo and Other Nigerian Languages, University of Nigeria, Nsukka Enugu State in 2019. Currently, Christopher C. Nwike undergoes a doctoral study (PhD) in Translation in the department of Linguistics, Igbo and Other Nigerian Languages, University of Nigeria, Nsukka.

He engages in translation jobs - textual translation and subtitles. He is an Igbo language teacher in Royal Crown Academy Orba Road Nsukka, Enugu State.

Mr. Nwike is a member of the Association of Translation Studies in Nigeria. He also obtained an academic merit award - The IfeOgbonna Prize in Honour of Aknu-ibiam As the Best Graduating Student Who Produced the Best Long Easy in Igbo Language in the 2014/2015 Academic Session. 